\title{
ВмJ Global Health Decolonising global health: if not now, when?
}

To cite: Büyüm AM, Kenney C, Koris A, et al. Decolonising global health: if not now, when? BMJ Global Health 2020;5:e003394. doi:10.1136/ bmjgh-2020-003394

$\mathrm{AMB}, \mathrm{CK}, \mathrm{AK}, \mathrm{LM}$ and $\mathrm{YR}$ contributed equally.

Received 8 July 2020 Accepted 9 July 2020

\section{Check for updates}

C) Author(s) (or their employer(s)) 2020. Re-use permitted under CC BY-NC. No commercial re-use. See rights and permissions. Published by BMJ.

'Duke Global Health Institute, Durham, North Carolina, USA ${ }^{2}$ Partners In Health, Boston, Massachusetts, USA

${ }^{3}$ Science Facilitation, FHI 360 , Durham, North Carolina, USA ${ }^{4}$ Clinical Operations, FHI Clinical Inc, Durham, North Carolina, USA

\section{Correspondence to}

Yadurshini Raveendran, Clinical Operations, FHI Clinical Inc, Durham, NC, United States; yadurshini.r@gmail.com

\author{
Ali Murad Büyüm, ${ }^{1}$ Cordelia Kenney, ${ }^{1}$ Andrea Koris, ${ }^{2}$ Laura Mkumba (D) , \\ Yadurshini Raveendran (10) ${ }^{4}$
}

\section{INTRODUCTION}

The severe acute respiratory syndrome coronavirus 2 (SARS-CoV-2) outbreak has grinded the world economy to a halt and upended health systems across the globe, contributing to disruptions in routine health services and skyrocketing rates of death. ${ }^{1}$ Against this backdrop, the pandemic highlights with renewed clarity the way structural violence operates both within and between countries. Defined as the discriminatory social arrangement that, when encoded into laws, policies and norms, unduly privileges some social groups while harming others, this concept broadens our thinking about drivers of disease. ${ }^{2}$ While the manifestation of inequity in each country or region is bound up in the local-to-global interface of historical, economical, social and political forces, COVID-19 disproportionately affects the world's marginalised, from Black, Indigenous and People of Color (BIPOC) communities in North America to migrant workers in Singapore. ${ }^{3}$ Health outcomes related to SARS-CoV-2 infection such as access to emergency services and prolonged intensive care, capacity to prevent infection through non-medical countermeasures like handwashing and social distancing, and economic security while in lockdown are all mediated by the confluence of global, regional and local systems of oppression.

This reality shows that the current global health ecosystem is ill equipped to address structural violence as a determinant of health, and the system itself upholds the supremacy of the white saviour. As early career global health practitioners, we see this pandemic as an opportunity to critically appraise what is not working and to offer an alternative vision for the future of global health. Global health needs integrated, decolonised approachesadvanced by individuals and institutionsthat address the complex interdependence between histories of imperialism with health, economic development, governance and
Summary box

The current global health ecosystem is ill equipped to address structural violence as a determinant of health.

- Histories of slavery, redlining, environmental racism and the predatory nature of capitalism underpin the design of global and public health systems, resulting in structural, racial and ethnic inequities within Black, Indigenous and People of Color (BIPOC) communities globally.

- While the manifestation of inequity in individual countries or regions is bound up in the local-toglobal interface of historical, economical, social and political forces, COVID-19 disproportionately affects BIPOC and other marginalised communities.

- Aside from direct health impacts on marginalised communities, exclusionary colonialist patterns that centre Euro-Western knowledge systems have also shaped the language and response to the pandemic - which, in turn, can have adverse health outcomes.

- Decolonising global health advances an agenda of repoliticising and rehistoricising health through a paradigm shift, a leadership shift and a knowledge shift.

While the global response to COVID-19 has so far reinforced injustices, the coming months present a window of opportunity to transform global health.

human rights. The global movement to Decolonize Global Health, led by students and other professionals, is one step towards this vision. ${ }^{4-8}$ In this commentary, we draw on examples that show how the most vulnerable and marginalised in society are ignored and exploited by design and in context-specific ways in the pandemic response. Through these examples, we call for a threefold shift in global health research, policy and practice.

\section{STRUCTURAL DETERMINANTS OF HEALTH FOR THE MARGINALISED MAJORITY}

The disadvantaged and marginalised make up the global majority. This 'marginalized majority' is strategically divided and 
disempowered by deep-seated racial, ethnic and financial inequities that fuel structural determinants of health. These kinds of power imbalances are by design and are by no means unique to the field of global health, yet health is often the locus of where many of these inequities intersect. Globally, histories of slavery, redlining, environmental racism and the predatory nature of capitalism underpin the design of global and public health systems, resulting in structural, racial and ethnic inequities within BIPOC communities. This pandemic widens these pre-existing inequities even further. Black and Brown people make up a significant portion of the essential workforce in many settler colonial states. ${ }^{9} 10$ Yet, they are often underpaid, underinsured and more likely to live in overcrowded, polluted and food insecure conditions that further increase their risk. Consequently, these communities have faced disproportionate rates of severe outcomes and deaths due to COVID-19. ${ }^{11}$ Without acknowledging these oppressive forces, the pandemic response will lack context-specific and targeted policies to address the structural racism that enforces these health disparities.

For example, Singapore's treatment of migrant workers illustrates how ignoring structural determinants of health has disastrous consequences for both those marginalised and the broader society. Singapore's 1.4 million migrant workers from India, Bangladesh, China and other nearby countries encompass one-third of the country's workforce. They leave their home countries for a better chance to sustain their families, break cycles of poverty and escape archaic forms of social hierarchies like the caste system. Despite playing a pivotal role in Singapore's development, migrant workers live in the margins of society, often cramped in dorms with 10-20 people to a room. This marginalisation led to Singapore ignoring them in its pandemic response. Initially credited as exemplary, Singapore's success has been reversed with a current infection rate of 1000 new cases per day, attributed to a spike in infections among migrant workers. Migrant workers are touted as 'the invisible backbone' of Singapore, yet SARS-CoV-2 has lifted the smokescreen to reveal how little these workers are actually valued, resulting in Singapore's failure to protect them from the virus and to protect the entire nation from a resurgence in cases. ${ }^{12}$

The impact of SARS-CoV-2 on Indigenous peoples in the USA is another potent example of how structural violence prevents equal access to health and appropriate medical care, and leads to disproportionate suffering and premature death. The systematic destruction and dispossession of Indigenous communities through violent colonial practices in the USA has left communities like the Navajo, which has among the highest infection rates in the country, ${ }^{13}$ with poor access to healthcare and a higher prevalence of comorbidities that increase their risk of contracting and dying from COVID-19. Furthermore, contemporary policies governing ethnic and racial categories in health reporting-in which Indigenous communities are often categorised as 'other'14-skew their official death rate from COVID-19 and result in the continued erasure of these communities. Not properly accounting racial and ethnic minorities in these totals ignores the severity of the pandemic's impact on these communities and erases the historical injustices that put them at greater risk in the first place.

\section{COLONIALIST PATTERNS SHAPE THE LANGUAGE AND RESPONSE TO THE PANDEMIC}

Aside from direct health impacts on marginalised communities, colonialist patterns that centre EuroWestern knowledge systems have also shaped the language and response to the pandemic - which, in turn, can have adverse health outcomes. The occupiers of the highest tiers of the social hierarchy have long used scapegoating in times of crisis to divert attention from root causes of the crisis at hand. During the Black Death, Jewish communities were systematically targeted; during the AIDS pandemic, men who have sex with men and others in the lesbian, gay, bisexual, transgender and queer community were ostracised; and now, in 2020 with the outbreak of SARS-CoV-2, we see a repeat of history. ${ }^{15}$

With labelling such as the 'Wuhan Virus' or the 'Chinese Virus', Chinese and other East Asian populations worldwide are being scapegoated and facing discrimination. Another way COVID-19 has further been racialised to uphold colonialist beliefs is seen with international news headlines such as 'Why don't Africans have the disease?' This attitude reveals an assumption that countries described as the 'Global South' could not be doing better than the so-called 'Global North'. ${ }^{16}$ As another example, French scientists suggested that Africa be the testing grounds for SARS-CoV-2 vaccine trials, invoking imperialist and colonialist ideologies that 'some lives were more valuable than others.' How, in March 2020 when this statement was made, could anyone practising global health deem it appropriate to use Black and Brown communities as 'guinea pigs' to promote the health of white, colonialist counterparts? ${ }^{17}$ The answer lies in the persistence of racist patterns that have yet to be fully dismantled.

Numerous success stories emerging from the 'Global South' counter this false narrative of Eurocentric superiority. Kerala, for example, a southwestern state in India, implemented highly coordinated state-wide lockdowns and test-and-trace strategies to effectively contain and control the virus. ${ }^{18}$ Among all the negative media coverage of India so far, however, this narrative of success is rarely highlighted or acknowledged. Likewise, in Africa, Senegal has become a leader in their pandemic response strategies, which include innovative technologies to reach entire populations with affordable tests for the virus. International coverage of the continent, however, instead has focused on the assumed inevitable failure of African nations to effectively respond to the pandemic, failures which are often caused by limited resources resulting from colonialism and modern-day 
imperialism. This representation is obviously biased, and is so because those with power to control the narrative around the pandemic continue to be disproportionately not from or based in the 'Global South'. ${ }^{19} 20$

This imbalance, driven by what WHO Director General Tedros Adhanom Ghebreyesus termed a 'colonial hangover', also plays out in what gets recommended as a good pandemic response strategy. ${ }^{21}$ Global health institutions based in the 'Global North', often lacking representation of key communities at the decision-making table, end up perpetuating a Eurocentric worldview that does not adequately consider most of the world's needs. The notion of simply 'copy-pasting' strategies like lockdowns and social distancing measures does not work in spaces like cramped migrant worker dormitories, refugee camps, urban slums or anywhere else the poorest and most marginalised are forced to reside. How can a family of 15 lock down in a slum complex that houses 700000 others? How can you practise good hygiene such as handwashing when water itself can be a scarce commodity? When the people in power represent only those with social dominance, the health needs of the marginalised majority inevitably get overlooked. In the wake of the pandemic, these colonial trends that we see time and time again must be reversed.

\section{A DECOLONISING AGENDA FOR HEALTH EQUITY, BEGINNING WITH COVID-19}

To uproot these sources of health inequity, all practitioners and researchers should leverage the disruptions caused by this pandemic to more critically reflect on their actions. More and more voices call for recognising and redressing these imbalances in global health. ${ }^{22-24}$ From activists to professors, non-governmental organisation leaders to clinicians, a decentralised alliance is building, demanding that global health practitioners meaningfully engage with global and local structures that drive health inequities. Within that coalition, the student-led decolonising global health movement serves an important but limited function: to help create space for critical, anticolonial reflection within large, influential and privileged institutions, agencies and organisations, so far often in high-income countries (HIC), that are responsible for driving global health discourse, 'knowledge' and funding flows. ${ }^{25}$

This movement advances an agenda of repoliticising and rehistoricising health. We believe that the movement broadly calls for the following:

1. Paradigm shift: Repoliticise global health by grounding it in a health justice framework that acknowledges how colonialism, racism, sexism, capitalism and other harmful '-isms' pose the largest threat to health equity. Without confronting the impact these interlocking systems have on health, global health activity, despite best intentions, remains complicit in the ill health of the world's marginalised. A paradigm shift involves individuals and institutions acknowledging that disease cannot be extracted or isolated from broader systems of coloniality. ${ }^{26} 27$ Organisations and donors should adapt their missions, programming and structures to account for this reality. Fundamentally, this shift means changing who sits at the table and rebuilding parts of the table itself.

2. Leadership shift: Leadership at global agenda-setting institutions does not reflect the diversity of people these institutions are intended to serve. First, the 'Global North' needs to 'lean out' on an individual, national and institutional level to stop reproducing racist and colonialist ideologies. ${ }^{28}$ Unsurprisingly, experiences from the 'Global South' show that it is a hotbed of innovation, and leaders in the 'Global South' must be recognised and elevated for their contributions. Second, gender disparities in global health leadership need to be addressed and remedied. In many global health institutions, women, especially women of colour, are under-represented and their voices are excluded in policy and programmatic formulation. ${ }^{29} 30$ A leadership shift would include more equitable representation in academic journals, leadership roles and faculty make-up, reflected, for example, in equitable first authorship positions for collaborators from the 'Global South' and women. ${ }^{31} 32$

3. Knowledge shift: To avoid perpetuating the kind of racist and colonialist pandemic response we see with COVID-19, it is vital to ensure knowledge flow is not unidirectional, but instead reciprocal with contributions from the 'Global South' driving discussions and practice, both locally and globally; a twofold knowledge shift. ${ }^{33}$ The first includes teaching students about inequitable global disease burdens while creating an enabling environment for critical inquiry into the racist and colonial histories that gave rise to these disease burdens. The second is to bridge geopolitical imbalances in global health education. For example, global health training programmes and knowledge resources are mostly offered in the English language, in HICs and at great cost, thus limiting access for people of other languages, and from less privileged backgrounds. To promote anticolonial thought by encouraging training and knowledge sharing without these obstacles, we need to change existing platforms and create new learning platforms for global health.

\section{CONCLUSION}

The pandemic response reveals with stark and sobering clarity that current paradigms of global health equity are insufficient in counteracting structural oppression. By focusing on individual risk factors and siloing funding based on disease, global health agendas-including pandemic responses-ignore how health risks are shaped structurally by laws, policies and norms, ranging from regional trade agreements and immigration policies to racial discrimination and gender-based violence. Structural inequities reproduced within the global health 
system itself-such as over-representation of affluent white men from HICs in global health leadership positions ${ }^{34}$-highlight the lack of critical engagement with the geopolitical determinants of health disparities. While the global response to COVID-19 has so far reinforced injustices, the coming months present a window of opportunity to transform global health. A student-led decolonising movement is one step. Now, the movement must expand in numbers and scope to create a more just and equitable future.

Twitter Ali Murad Büyüm @alimuradbuyum, Cordelia Kenney @CordeliaKenney, Andrea Koris @andreakoris, Laura Mkumba @laura_mkumba and Yadurshini Raveendran @YadurshiniR

Acknowledgements We thank Dr Seye Abimbola for his guidance and support during the writing process of this commentary. We thank Dr Madhukar Pai, Dr Gavin Yamey and Dr Kearsley Stewart for their mentorship.

Contributors AMB, CK, AK, LM and YR equally contributed to the planning, writing and editing of this piece.

Funding The authors have not declared a specific grant for this research from any funding agency in the public, commercial or not-for-profit sectors.

Competing interests None declared.

Patient consent for publication Not required.

Provenance and peer review Commissioned; internally peer reviewed.

Data availability statement There is no additional data available from this work.

Open access This is an open access article distributed in accordance with the Creative Commons Attribution Non Commercial (CC BY-NC 4.0) license, which permits others to distribute, remix, adapt, build upon this work non-commercially, and license their derivative works on different terms, provided the original work is properly cited, appropriate credit is given, any changes made indicated, and the use is non-commercial. See: http://creativecommons.org/licenses/by-nc/4.0/.

Author note Statement of positionality: We are graduate students from an elite postsecondary institution in the USA. We acknowledge that 'decolonization' first and foremost calls for a dismantling of white supremacist systems, repatriation of Indigenous land and reparations for colonialism and slavery, but in this piece, we use the term to acknowledge historical legacies of colonialism and redress power imbalances in global health.

\section{ORCID iDs}

Laura Mkumba http://orcid.org/0000-0002-7402-481X

Yadurshini Raveendran http://orcid.org/0000-0002-0523-0097

\section{REFERENCES}

1 Livemint. How covid-19 response disrupted health services in rural India, 2020. Available: https://www.livemint.com/news/india/ how-covid-19-response-disrupted-health-services-in-rural-india11587713155817.html [Accessed 20 May 2020].

2 Farmer PE, Nizeye B, Stulac S, et al. Structural violence and clinical medicine. PLoS Med 2006;3:e449.

3 Koh D. Migrant workers and COVID-19. Occup Environ Med 2020 doi:10.1136/oemed-2020-106626. [Epub ahead of print: 08 Jun 2020].

4 Duke Decolonizing global health Working group. Available: https:// sites.duke.edu/dukedgh/ [Accessed 23 Jun 2020]

5 Harvard Chan Student Committee for the Decolonization of Public Health. Boston 677 Huntington Avenue, MA 02115 +1495-1000. Harvard Chan student Committee for the decolonization of public health. Available: https://www.hsph.harvard.edu/decolonizingglobal-health-so/ [Accessed 23 Jun 2020].

6 Twitter. Karolinska Decolonizing Global Health (@KarolinskaDGH). Available: https://twitter.com/karolinskadgh [Accessed 23 Jun 2020].

7 Syllabus and Resources. Decolonizing bodies in public health. Available: http://decolonizingph.weebly.com/syllabus.html [Accessed 23 Jun 2020].

8 Decolonizing public health. Available: http://umsphteachin.weebly. $\mathrm{com} /[$ Accessed 23 Jun 2020
9 Centers for Disease Control and Prevention. Coronavirus disease 2019 (COVID-19), 2020. Available: https://www.cdc.gov/coronavirus/ 2019-ncov/need-extra-precautions/racial-ethnic-minorities.html [Accessed 20 May 2020].

10 Black people in England and Wales are four times more likely to die from the coronavirus, data shows. Available: https://www.cbsnews. $\mathrm{com} /$ news/coronavirus-britain-black-people-likely-die/ [Accessed 20 May 2020]

11 Johns Hopkins Coronavirus Resource Center. State testing data by race. Available: https://coronavirus.jhu.edu/data/us-state-dataavailability [Accessed 20 May 2020].

12 Time. Virus Outbreak Among Singapore's Migrants Serves as Warning. Available: https://time.com/5825261/singaporecoronavirus-migrant-workers-inequality/ [Accessed 20 May 2020].

13 NPR org. Coronavirus infections continue to rise on Navajo nation. Available: https://www.npr.org/sections/coronavirus-live-updates/ 2020/05/11/854157898/coronavirus-infections-continue-to-rise-onnavajo-nation [Accessed 20 May 2020]

14 PBS NewsHour. How COVID-19 is impacting Indigenous peoples in the U.S, 2020. Available: https://www.pbs.org/newshour/nation/howcovid-19-is-impacting-indigenous-peoples-in-the-u-s [Accessed 20 May 2020].

15 Coates M. Covid-19 and the rise of racism. BMJ 2020;369:m1384.

16 Welle D. Africa has been spared so far from coronavirus. why? Available: https://www.dw.com/en/africa-has-been-spared-so-farfrom-coronavirus-why/a-52382666 [Accessed 20 May 2020].

17 CNN. French doctors' proposal to test Covid-19 treatment in Africa slammed as "colonial mentality". Available: https://www.cnn.com/ 2020/04/07/africa/french-doctors-africa-covid-19-int//index.html [Accessed 20 May 2020].

18 Kurian OC. How the Indian state of Kerala flattened the coronavirus curve, 2020. Available: https://www.theguardian.

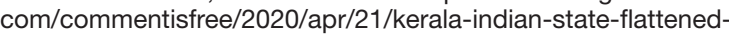
coronavirus-curve [Accessed 23 Jun 2020]

19 Hirsch A. Why are Africa's coronavirus successes being overlooked? 2020. Available: https://www.theguardian.com/commentisfree/ 2020/may/21/africa-coronavirus-successes-innovation-europe-us [Accessed 23 May 2020].

20 Sihlongonyane MF. The challenges of Theorising about the global South;17.

21 BBC News. Coronavirus: Africa will not be testing ground for vaccine, says WHO - BBC News. Available: https://www.bbc.com/ news/world-africa-52192184 [Accessed 24 May 2020].

22 Abimbola S. The foreign gaze: authorship in academic global health. BMJ Glob Health 2019;4:e002068.

23 Tuck E, Yang KW. Decolonization is not a metaphor. Decolonization Indig Educ Soc 2012;1.

24 The Lancet Global Health. Decolonising COVID-19. Lancet Glob Health 2020;8:e612.

25 IHP. Unpacking power and knowledge in global health: some reflections from the emerging voices 2018 cohort, 2018. Available: https://www.internationalhealthpolicies.org/blogs/unpackingpower-and-knowledge-in-global-health-some-reflections-from-theemerging-voices-2018-cohort/ [Accessed 24 May 2020].

26 Paul E, Brown GW, Ridde V. COVID-19: time for paradigm shift in the nexus between local, National and global health. BMJ Glob Health 2020;5:e002622.

27 Global health needs a paradigm shift post coronavirus pandemic Available: https://www.outlookindia.com/website/story/opinionglobal-health-needs-a-paradigm-shift-post-coronavirus-pandemic/ 351923 [Accessed 24 May 2020].

28 Pai M. Global Health Needs To Be Global \& Diverse. Available: https://www.forbes.com/sites/madhukarpai/2020/03/08/globalhealth-needs-to-be-global--diverse/ [Accessed 23 May 2020].

29 Times Higher Education (THE). Women in science are battling both Covid-19 and the patriarchy [Internet], 2020. Available: https://www. timeshighereducation.com/blog/women-science-are-battling-bothcovid-19-and-patriarchy [Accessed 23 May 2020].

30 Wenham C, Smith J, Morgan R, et al. COVID-19: the gendered impacts of the outbreak. Lancet 2020;395:846-8.

31 Hedt-Gauthier BL, Jeufack HM, Neufeld NH, et al. Stuck in the middle: a systematic review of authorship in collaborative health research in Africa, 2014-2016. BMJ Glob Health 2019;4:e001853.

32 Pinho-Gomes A-C, Peters S, Thompson K, et al. Where are the women? gender inequalities in COVID-19 research authorship. BMJ Glob Health 2020;5:e002922.

33 R. Montenegro C, Bernales M, Gonzalez-Aguero M. Teaching global health from the South: challenges and proposals. Crit Public Health 2020;30:127-9.

34 Report 2020 - Global Health 50/50 [Internet]. Available: https:// globalhealth5050.org/2020report/ [Accessed 23 Jun 2020]. 